\title{
Foliar application of boron improved the yield and quality of wheat (Triticum aestivum L.) in a calcareous field
}

\author{
Muhammad Abdullah Saleem ${ }^{* 1}$, Muhammad Tahir ${ }^{1}$, Taseer Ahmad ${ }^{1}$ and Muhammad Naveed Tahir ${ }^{2}$ \\ ${ }^{1}$ Department of Agronomy, University of Agriculture Faisalabad \\ ${ }^{2}$ Institute of Soil and Environmental Sciences, University of Agriculture Faisalabad \\ [Received: December 27, 2020 Accepted: February 21, 2020 Published Online: February 25, 2020]
}

\begin{abstract}
Boron (B) is vital for crops and helps in grain setting, but its deficiency is increasing due to its fixation in calcareous soils of Pakistan which results in premature opening of spikelets and failure of grain production in wheat thus leading to the reduced crop yield and economic return. To overcome this problem, a field trial was carried out at Agronomy Research Farm, University of Agriculture Faisalabad for analyzing the effectiveness of different levels of B spray on wheat. Randomized complete block design (RCBD) with three replications was used for allocation of treatments. Treatments included were eight levels of $B(0.5 \%, 1 \%, 1.5 \%, 2 \%, 2.5 \%, 3 \%, 3.5 \%, 4 \%)$ along with water spray and control (without any treatment). Boron solution of different concentrations was prepared by dissolving required quantity of boric acid in water. Foliar application of $1.5 \%$ B solution produced maximum spike length $(12.66 \mathrm{~cm})$, grains spike ${ }^{-1}(50)$, seed index/1000-grains weight $(35 \mathrm{~g})$, biological yield $(9.85 \mathrm{t}$

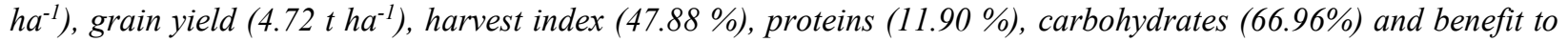
cost ratio (1.31) when compared with all other levels. Overall, it is depicted that $1.5 \%$ B applied by foliar spray at booting stage triggered both yield and quality of wheat.
\end{abstract}

Keywords: Boron, boric acid, calcareous soil, foliar spray, wheat

\section{Introduction}

Wheat is one of the major crops in agriculture sector. It is most valuable among cereals in Pakistan. Wheat demand is increasing continuously in Pakistan with the expansion of population. The only way to feed the population is to boost up the yield of edible grains. Production of any crop can be increased either by spreading cultivable area or by increasing production per unit area (Muhmood et al., 2014).

Management of crop nutrition by applying macro and micro-nutrients is important to obtain high yield (Arif et al. 2006). Farmers are still approaching the traditional way of cropping in which they are continuously ignoring the usage of micronutrients. Micronutrients have prominent effects on dry matter, grain yield and straw yield in wheat (Asad and Rafique, 2000). Among micronutrients, $B$ helps the plant to reduce sterility and can contribute to biofortification (Rehman and Farooq, 2013). Deficiency of B severely affects wheat, rice and cotton yield in Pakistan (Imtiaz et al., 2010).

Boron is a component of cell wall, helps in the stability of membrane (Brown et al., 2002), regulates germination of pollens (Wang et al., 2003) and plays important part in grain setting (Tahir et al., 2009). Boron has many beneficial impacts on crop growth and development. However, sometimes soil applied B is not available to plants due to many reasons. Our soils are poor in micronutrient, especially B, due to leaching (Yan et al., 2006) and fixation of B in alkaline calcareous nature of soils (Narimani et al., 2010). Applying micronutrients as foliar spray is an alternate and has been documented more efficient in comparison to broadcast or soil application by different researchers (Torun et al., 2001). Tahir et al. (2009) found the highest wheat yield with B spray at booting stage. Arif et al. (2006) documented that foliar sprays of nutrients at different growth stages increased wheat yield. In Pakistan, Chaudhry et al. (2007) observed an increased yield of cereals in response to B application. Synergetic relationship of $\mathrm{B}$ with uptake of other nutrients (N, P, K, Zn, Cu and Fe) was found after B application (Ahmed et al., 2011). Boron helped in uptake of $\mathrm{N}$ and $\mathrm{P}$ as concentrations of these two nutrients were increased in plant samples with application of B (Muhmood et al., 2014).

Deficiency of B have adverse impacts on growth as well as metabolic processes in plants (Shireen et al., 2018). However, higher accumulation of B leads to toxic effects in plants (Reid, 2007). Therefore, a field research was

\footnotetext{
*Email: abdullahsaleem65@gmail.com
} 
conducted to identify the optimum concentration of B to achieve higher economic yield from wheat.

\section{Materials and Methods}

\section{Trial location and soil analysis}

Research was conducted at Agronomy Research Area in the University of Agriculture Faisalabad, Punjab, Pakistan. Soil was sampled (from $20 \mathrm{~cm}$ depth) before crop sowing and analysed for soil $\mathrm{pH}$, organic matter, texture, total nitrogen, EC, available phosphorus, $\mathrm{B}$ contents and extractable potassium using standard methods.

\section{Field experiment}

\section{Seed collection}

Wheat variety "Ujhala-2016" with seed rate $125 \mathrm{~kg} \mathrm{ha}^{-1}$ was sown as a trial crop and the seeds were taken from Agronomy Research Farm, University of Agriculture Faisalabad.

\section{Soil preparation}

Whole field was flood-irrigated prior to ploughing; the practice is commonly known as Rauni irrigation. Field was ploughed three times with cultivator for providing favorable conditions for seed germination when soil was at field capacity. Planker was used to level the field.

\section{Experimental design}

Research was conducted using randomized complete block design having net plot size of $5.0 \mathrm{~m} \times 2.25 \mathrm{~m}$ and all the treatments were replicated thrice.

Eight levels of B $(0.5 \%, 1 \%, 1.5 \%, 2 \%, 2.5 \%, 3 \%$, $3.5 \%, 4 \%$ ) along with foliar spray of water (without B) and a control (not receiving any treatment) were used in experiment. All the levels were made by dissolving required quantity of boric acid $(17 \% \mathrm{~B})$ in water and were sprayed at the time of booting. The concentrations for treatments were prepared by calculating the boric acid required for the desired amount of $\mathrm{B}$ and then dissolving that amount of boric acid into water needed for the research plot. All the treatments were applied at same time with similar equipment.

\section{Plant protection measures}

Seed treatment with Hombre excel $\left(2 \mathrm{~mL} \mathrm{~kg}^{-1}\right.$ seed) was done to prevent the seed borne diseases. Trial remained disease free but there was weed infestation at early growth stage which was copped with application of weedicides. Infesting weeds population was broad leafed and the active ingredient Buctral super was sprayed to control the weed population.

\section{Fertilizer and irrigation}

Nutrients, N, P and K with a dose 120:85:60 $\mathrm{kg} \mathrm{ha}^{-1}$ were added in the soil to nourish the crop. Sources for N and $\mathrm{P}$ fertilization were urea and DAP, respectively, while MOP was used to apply K. All these fertilizers were applied in soil before sowing of crop except urea, which was used in split doses i.e. half before sowing and half with $1^{\text {st }}$ irrigation. Crop during growth season, was irrigated five times at various stages viz. tillering, booting, grain formation and dough stage.

\section{Harvesting and threshing}

Crop was harvested in the middle of April when crop completed its maturity and spikes were turned golden brown. Spikes were threshed using mining thresher after ten days of sun-drying.

\section{Data collection}

Various growth and yield parameters were observed while conducting this research. Data for all growth parameters was taken 75,85 and 95 days after sowing (DAS) because all the treatments were applied at booting which starts from 85-90 DAS in wheat. Data recorded before and after treatments application showed the effect of $\mathrm{B}$ on growth parameters. Leaf area index (LAI) was measured using formula as under

$\mathrm{LAI}=\frac{\text { leaf area }}{\text { ground area }}$

Leaf area of the plant was measured using leaf area meter. Whereas, crop growth rate (CGR) was calculated by following formula

$$
\mathrm{CGR}=\frac{W 2-W 1}{p(t 2-t 1)}
$$

Where, W2 is dry weight of plant $/ \mathrm{m}^{2}$ recorded at time $\mathrm{t} 2$, W1 is the dry weight of plant $/ \mathrm{m}^{2}$ recorded at time t1. P is the ground area and $\mathrm{t} 2-\mathrm{t} 1$ is the time interval between readings.

Net assimilation rate (NAR) was calculated as

$$
\mathrm{NAR}=\frac{W 2-W 1}{\mathrm{t} 2-\mathrm{t} 1} \times \frac{\log L 2-\log L 1}{22-L 1}
$$

Where, W1 and W2 is dry weight of whole plant at time $\mathrm{t} 1$ and $\mathrm{t} 2$, respectively. $\mathrm{L} 1$ and $\mathrm{L} 2$ are leaf area at $\mathrm{t} 1$ and $\mathrm{t} 2$, respectively. $\mathrm{t} 1-\mathrm{t} 2$ are time interval in days. 
Table 1: Analysis of experimental soil

\begin{tabular}{llc}
\hline \multicolumn{1}{c}{ Component } & Unit & Value \\
\hline $\mathrm{pH}$ & - & 7.9 \\
$\begin{array}{l}\text { Electrical conductivity } \\
\text { (ECe) }\end{array}$ & $\mathrm{dS} \mathrm{m}{ }^{-1}$ & 2.1 \\
Organic matter (O.M) & $\%$ & \\
Total Nitrogen (T.N) & $\%$ & 0.80 \\
Phosphorus (P) & $\mathrm{mg} \mathrm{kg}^{-1}$ & 0.04 \\
Potassium (K) & $\mathrm{mg} \mathrm{kg}^{-1}$ & 4.34 \\
Zinc (Zn) & $\mathrm{mg} \mathrm{kg}^{-1}$ & 0.79 \\
Boron (B) & $\mathrm{Mg} \mathrm{kg}^{-1}$ & 0.41 \\
Sand & $\%$ & 46 \\
Silt & $\%$ & 38 \\
Clay & $\%$ & 16 \\
Soil class = Sandy loam & - & - \\
\hline
\end{tabular}

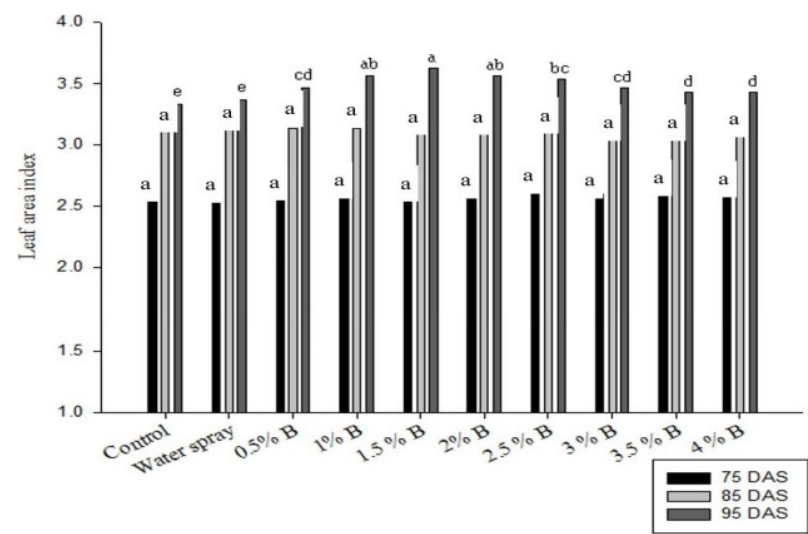

Figure 1: Effect of foliar applied B on LAI of wheat (Triticum aestivum L.)

Values with different letters are statistically significant at $5 \%$ probability of LSD test.

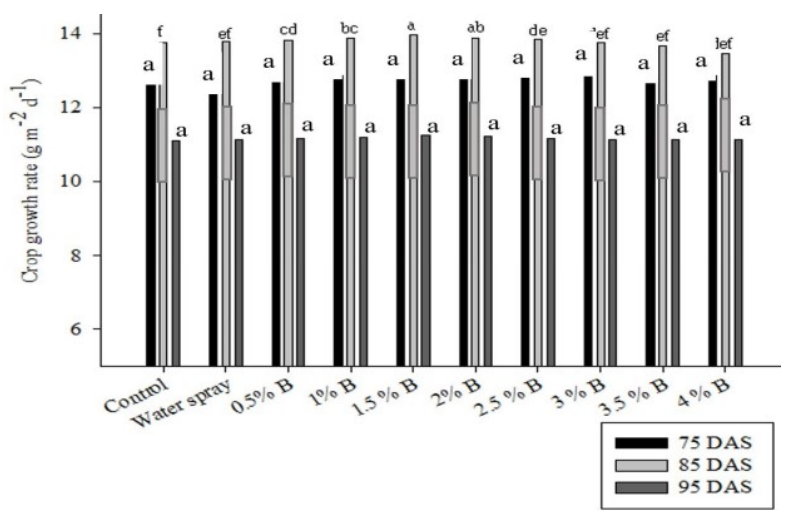

Figure 2: Effect of foliar applied B on CGR $\left(\mathrm{g} \mathrm{m}^{-2} \mathrm{~d}^{-1}\right)$ of wheat (Triticum aestivum $\mathrm{L}$.)

Values with different letters are statistically significant at 5\% probability of LSD test).
Productive tillers were counted after the application of $\mathrm{B}$ by foliar spray at the stage of flag leaf emergence. Plant height and spike length were measured just before the harvesting, while, grains spike ${ }^{-1}, 1000$-grain weight, grain yield $\left(\mathrm{t} \mathrm{ha} \mathrm{a}^{-1}\right)$, biological yield $\left(\mathrm{t} \mathrm{ha} \mathrm{a}^{-1}\right)$, straw yield $\left(\mathrm{t} \mathrm{ha} \mathrm{C}^{-1}\right)$ and Harvest Index (H.I) were observed after harvesting.

\section{Biochemical parameters}

Besides yield parameters, protein and carbohydrate contents of grains were also analysed for quality determination. Proteins were analysed using Kjeldahl method and the instrument used was Kjeldahl apparatus (UDK 126D). Values obtained after using Kjeldahl apparatus were multiplied with 6.25 which is a factor to find out the protein contents in wheat. Carbohydrates were recorded with gravimetric method.

Benefit cost ratio (BCR) of the experiment was also calculated by using following formula

$$
\mathrm{BCR}=\frac{\tau \text { otal benefits }}{\tau \text { otal cost }}
$$

\section{Statistical analysis}

Data recorded was analysed statistically at 5\% probability level of LSD test (Steel et al. 1997).

\section{Results and Discussion}

Physical and chemical analysis of the soil before sowing revealed that soil textural class was sandy loam. Result of soil parameters is demonstrated in Table 1.

\section{Growth parameters}

Foliar applied B positively affected the LAI of wheat. Data recorded for LAI is presented in Figure 1. An increase of $10 \%$ in LAI was recorded with $1.5 \%$ B applied by foliar spray when compared with control._Nadim et al. (2011) also found increase in LAI with B nutrition. Boron might has played role in division of cells in leaf and increased the leaf area. Cohen and Lepper (1977) have also reported the role of B in cell division. Crop growth rate tells about dry matter accumulation per unit area per unit time. CGR is usually correlated to the solar radiation interception. Various factors such as solar radiations, water availability and nutrient supply affect it. Foliar spray of $\mathrm{B}$ at booting stage significantly affected CGR. It showed elevating trend with increasing concentration of $\mathrm{B}$ but after a peak point, it started a decline. Data recorded for CGR is presented in Figure 2. Significantly the highest CGR was observed with $1.5 \% \mathrm{~B}$ spray at booting which was $1.23 \%$ higher than 
control. This increase in CGR is in line with the results of Nadim et al. (2013) as they observed significantly higher CGR value for wheat with application of B. Additionally, Nadim et al. (2012) observed higher CGR with B application in wheat. Net assimilation rate is dry matter augmentation per unit leaf area for a unit of given time. It reveals the photosynthetic efficiency of leaves. Tahir et al. (2009) documented that availability of B increased leaf expansion which increased the photosynthetic efficiency of the plant and this increased photosynthesis which ultimately improved the growth rate of the whole crop. Foliar spray of $\mathrm{B}$ at booting stage resulted in significant increase in NAR (Figure 3)._An increase of $1.6 \%$ was observed in NAR with B spray in comparison to control. Increase in NAR is due to increased photosynthetic activity of plants (Watson and Hayashi, 1965). Likewise, Nadim et al. (2013) also reported that application of $\mathrm{B}$ produced the maximum NAR among other micronutrients applied. Increase in photosynthesis resulted in increased NAR value of the wheat (Reddy, 2004). This statement can be evidenced by Manal et al. (2010) as they indicated that B played its role in increasing chlorophyll contents of leaves, so, helped in enhancing photosynthetic activity.

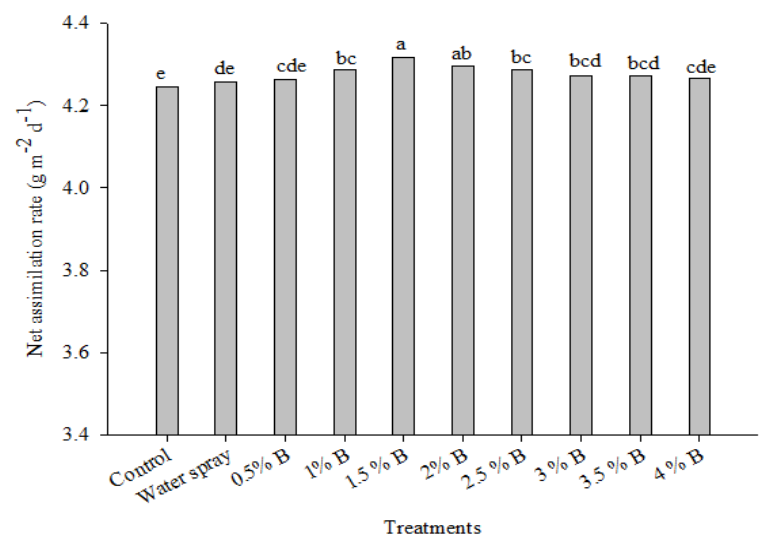

Figure 3: Effect of foliar applied B on NAR $\left(\mathrm{g} \mathrm{m}^{-2} \mathrm{~d}^{-1}\right)$ of wheat (Triticum aestivum $\mathrm{L}$.)

(Values with different letters are statistically significant at 5\% probability of LSD test).

Plant height is a genetic trait and may vary with nutrition management. Data recorded for plant height is given in Table 2. Results from the current experiment reflected that B spray did not affect plant height either in positive or negative way. Plant height recorded was nonsignificant. This may be due to B spray at later growth stage. Wheat goes through stem elongation stage prior to booting. Fakir et al. (2016) have also stated non-significant outcomes for plant height with B spray. Furlani et al. (2003) too reported that plant height does not vary with increasing B concentration, however it depends upon genetic makeup of each variety.

\section{Yield parameters}

\section{Tillers $\mathbf{m}^{-2}$}

These are considered the most imperative among all yield determining parameters as Tahir et al. (2009) endorsed that yield of wheat mainly depends on productive/fertile tillers in the field. Foliar application of B at booting stage significantly affected fertile tillers. The data noted is given in Table 2. Significantly, the highest number for productive tillers $\left(384.33 \mathrm{~m}^{-2}\right)$ was found in treatment where $1.5 \% \mathrm{~B}$ was sprayed at booting stage of the crop. An increase of $1 \%$ was observed in productive tillers with B spray in comparison to control. Similarly, Nazim et al. (2005) reported improvement in productive tillers with foliar application of B. Ahmad and Irshad (2011) advocated increase in productive tillers $\mathrm{m}^{-2}$ with application of $\mathrm{B}$. Those tillers which do not bear grains in their spikes and some do not even bear spikes are considered as nonproductive. Non-productive tillers are not as much important as productive tillers but transformation of nonproductive to productive tillers is important as productive tillers are directly related to the yield of wheat. For the higher yields, there must be a smaller number of nonproductive tillers in the field. Foliar application of B resulted significantly in reducing non-productive tillers $\mathrm{m}^{-2}$. The Table 2_reflects the recorded data. Most unfertile tillers $\left(10.33 \mathrm{~m}^{-2}\right)$ were recorded in control. Reduction in unfertile tillers is due to B foliar spray at booting stage as B played a key role in grain formation. Boron reduced sterility of wheat and produced grains in each spike, hence increased productive tillers by decreasing unfertile tillers in the field. These findings are similar to Tahir et al. (2009) as they documented a significant role of B in grain setting in wheat. Boron spray at booting stage did not affect the total tillers as tillering is an early stage while foliar application of B was done at lateral stage. Data recorded for total tillers is given in Table 2.

\section{Spike length}

It is an important parameter to consider. Data recorded for spike length is provided in Table 2. Highest spike length $(12.66 \mathrm{~cm})$ was observed with $1.5 \%$ B spray at booting stage in comparison to control. The lowest spike length $(8.33 \mathrm{~cm})$ was observed from control. Fakir et al. (2016) have also observed and interpreted increased spike length by B spray at booting stage. Leghari et al. (2016) also documented an increase in the spike length of wheat with B application. 
Table 2: Yield responses of wheat (Triticum aestivum L.) to different levels of foliar applied B

\begin{tabular}{|c|c|c|c|c|c|c|c|c|c|c|c|c|}
\hline Treatment & $\begin{array}{l}\text { Plant } \\
\text { height } \\
\text { (cm) }\end{array}$ & $\begin{array}{l}\text { Productive } \\
\text { Tillers }\left(\mathrm{m}^{-2}\right)\end{array}$ & $\begin{array}{l}\text { Non- } \\
\text { Productive } \\
\text { Tillers }\left(\mathrm{m}^{-2}\right)\end{array}$ & $\begin{array}{l}\text { Total } \\
\text { tillers } \\
\left(\mathrm{m}^{-2}\right)\end{array}$ & $\begin{array}{l}\text { Spike length } \\
\text { (cm) }\end{array}$ & $\begin{array}{l}\text { Grains } \\
\text { spike }^{-1}\end{array}$ & $\begin{array}{l}\text { Grain yield } \\
\left(\mathrm{t} \mathrm{ha}^{-1}\right)\end{array}$ & $\begin{array}{l}\text { Biological } \\
\text { yield }\left(\mathrm{t} \mathrm{ha}^{-1}\right)\end{array}$ & $\begin{array}{l}\text { Straw yie } \\
\left(\mathrm{t} \mathrm{ha}^{-1}\right)\end{array}$ & $\begin{array}{l}11000 \text { grain } \\
\text { weight }(g)\end{array}$ & H.I (\%) & BCR \\
\hline Control & $97.0 \mathrm{a}$ & $380.33 \mathrm{e}$ & $10.33 \mathrm{a}$ & $391.3 \mathrm{a}$ & $8.33 \mathrm{~d}$ & $45.66 \mathrm{e}$ & $4.42 \mathrm{~g}$ & $9.41 \mathrm{f}$ & $4.993 \mathrm{c}$ & $32.66 \mathrm{c}$ & $46.97 \mathrm{c}$ & 1.23 \\
\hline Water spray & $96.6 \mathrm{a}$ & $381.00 \mathrm{cde}$ & $10.00 \mathrm{ab}$ & $390.3 \mathrm{a}$ & $9.00 \mathrm{~cd}$ & $46.33 \mathrm{de}$ & $4.45 \mathrm{f}$ & $9.45 \mathrm{f}$ & $5.000 \mathrm{c}$ & $32.66 \mathrm{c}$ & $47.09 \mathrm{c}$ & 1.24 \\
\hline $0.5 \% \mathrm{~B}$ foliar spray & $96.3 \mathrm{a}$ & $381.33 \mathrm{cde}$ & $9.33 \mathrm{abc}$ & $390.6 \mathrm{a}$ & $10.00 \mathrm{bc}$ & $47.00 \mathrm{~d}$ & $4.53 \mathrm{de}$ & $9.59 \mathrm{~d}$ & $5.053 \mathrm{bc}$ & $33.66 \mathrm{c}$ & $47.30 \mathrm{bc}$ & 1.26 \\
\hline $1 \%$ B foliar spray & $97.6 \mathrm{a}$ & $382.67 \mathrm{abc}$ & $9.00 \mathrm{bc}$ & $391.6 \mathrm{a}$ & $11.00 \mathrm{~b}$ & $48.33 \mathrm{bc}$ & $4.63 \mathrm{~b}$ & $9.76 \mathrm{~b}$ & $5.130 \mathrm{a}$ & $34.00 \mathrm{ab}$ & $47.47 \mathrm{~b}$ & 1.29 \\
\hline $1.5 \% \mathrm{~B}$ foliar spray & $98.0 \mathrm{a}$ & $384.33 \mathrm{a}$ & $6.67 \mathrm{e}$ & $391.0 \mathrm{a}$ & $12.66 \mathrm{a}$ & $50.00 \mathrm{a}$ & $4.72 \mathrm{a}$ & $9.85 \mathrm{a}$ & $5.136 \mathrm{a}$ & $35.00 \mathrm{a}$ & $47.88 \mathrm{a}$ & 1.31 \\
\hline $2 \%$ B foliar spray & $98.0 \mathrm{a}$ & $383.33 \mathrm{ab}$ & $7.00 \mathrm{e}$ & $390.3 \mathrm{a}$ & $10.66 \mathrm{~b}$ & $48.66 \mathrm{~b}$ & $4.63 \mathrm{bc}$ & $9.75 \mathrm{bc}$ & $5.116 \mathrm{a}$ & $33.66 \mathrm{bc}$ & $47.52 \mathrm{~b}$ & 1.26 \\
\hline $2.5 \% \mathrm{~B}$ foliar spray & $97.0 \mathrm{a}$ & 382.33 bcd & $7.67 \mathrm{de}$ & $390.0 \mathrm{a}$ & $10.00 \mathrm{bc}$ & $47.33 \mathrm{~cd}$ & $4.61 \mathrm{c}$ & $9.70 \mathrm{c}$ & $5.093 \mathrm{ab}$ & $33.66 \mathrm{bc}$ & $47.51 \mathrm{~b}$ & 1.23 \\
\hline $3 \%$ B foliar spray & $97.0 \mathrm{a}$ & $381.33 \mathrm{cde}$ & $8.67 \mathrm{~cd}$ & $389.3 \mathrm{a}$ & $9.66 \mathrm{bcd}$ & $46.33 \mathrm{de}$ & $4.55 \mathrm{~d}$ & $9.58 \mathrm{~d}$ & $5.033 \mathrm{bc}$ & $33.33 \mathrm{bc}$ & $47.47 \mathrm{~b}$ & 1.19 \\
\hline $3.5 \%$ B foliar spray & $96.0 \mathrm{a}$ & 381.00 cde & $8.67 \mathrm{~cd}$ & $389.3 \mathrm{a}$ & $9.66 \mathrm{bcd}$ & $46.66 \mathrm{de}$ & $4.54 \mathrm{de}$ & $9.56 \mathrm{de}$ & $5.026 \mathrm{c}$ & $32.66 \mathrm{c}$ & $47.45 \mathrm{~b}$ & 1.17 \\
\hline $4 \%$ B foliar spray & $96.0 \mathrm{a}$ & $380.67 \mathrm{de}$ & $8.67 \mathrm{~cd}$ & $390.0 \mathrm{a}$ & $9.66 \mathrm{bcd}$ & $46.33 \mathrm{de}$ & $4.52 \mathrm{e}$ & $9.52 \mathrm{e}$ & $5.000 \mathrm{c}$ & $32.66 \mathrm{c}$ & $47.48 \mathrm{~b}$ & 1.15 \\
\hline LSD value & - & 1.68 & 1.25 & - & 1.39 & 1.05 & 0.022 & 0.05 & 0.06 & 1.06 & 0.34 & - \\
\hline
\end{tabular}

Values with different letters are statistically significant at $5 \%$ probability of LSD test.

\section{Grains spike-1}

It is among the most imperative components to determine yield which is affected by many factors including nutrient management. Data recorded is provided in Table 2 which showed that significantly the highest grains spike ${ }^{-1}$ (50) were counted from treatment with $1.5 \%$ B spray at booting stage with $9.5 \%$ more increment than control. The lowest grains spike ${ }^{-1}$ (45.66) were counted from control. As B plays a significant role in assimilates translocation, therefore, it helped in grain set and produced higher grains spike $^{-1}$. There was an observation which indicated $9.5 \%$ increase in grains spike ${ }^{-1}$ with $\mathrm{B}$ spray. These results are also possibly due to $\mathrm{B}$ role in grain setting. Boron may have played its role in reducing sterility and increased grain development in spike. Nadim et al. (2011) stated that B application helped in improving grains spike ${ }^{-1}$ in wheat. Muhmood et al. (2014) also observed significantly the higher grains spike ${ }^{-1}$ with B application. Survival of fertile florets is considered important to achieve high yield as unfertile florets cause decrease in number of grains and so the grain yield. Foliar application of B reduced the floret degradation up to $6 \%$ and floret abortion rate up to $22 \%$ (Zheng et al., 2014).

\section{Seed index/1000-grain weight}

Spray of B at booting significantly influenced 1000grain weight. The data recorded is given in Table 2. Highest 1000 -grain weight $(35.00 \mathrm{~g})$ was produced with $1.5 \% \mathrm{~B}$ spray at booting stage. The minimum 1000-grains weight $(32.66 \mathrm{~g})$ was recorded in control. There was an escalation of $7.1 \%$ in grains weight with B spray. This increase in grains weight is primarily owing to role of B in grain setting and sugar translocation. Boron may have played its role in translocation and that is why grains gained more weight. Current results are endorsed with results presented by Raza et al. (2014) as they also advocated significant increase in 1000-grain weight in wheat with B spray. Furthermore,
Rehman et al. (2012) also discussed increased 1000-grain weight with B spray at booting stage.

\section{Biological yield}

It is important in measuring photosynthetic activity of crop. Data recorded is given in Table 2. Boron spray significantly affected biological yield. Statistically significant and the highest biological yield $\left(9.85 \mathrm{t} \mathrm{ha}^{-1}\right)$ was obtained with $1.5 \% \mathrm{~B}$ spray at booting stage. It was increased by $4.6 \%$ with B spray. Increase in grain weight is the possible reason to increase the biological yield as grains are component of biological yield. Current outcomes are similar to Khan et al. (2010) as they observed increase in biological yield with application of micronutrients at different growth stages of wheat. Similarly, Ali et al. (2009) also reported a significant improvement in biological yield when they applied B.

\section{Grain yield}

It is cumulative result of different yield contributing parameters. It is the most important parameter to be discussed as it is the outcome of any cereal crop. Grain yield per unit area can be maximized by good management practices including timely and right amount of fertilizer application. Data recorded from current experiment is given in Table 2. Observations revealed that significantly the maximum grain yield $\left(4.72 \mathrm{t} \mathrm{ha}^{-1}\right)$ was observed in treatment with $1.5 \% \mathrm{~B}$ spray at booting stage. The calculated surge in grain yield with B spray was $6.7 \%$. This increase in grain yield might be due to $\mathrm{B}$ role in pollen tube germination, grain setting and sugar translocation. Boron helped in increasing grain number and weight which resulted in the higher grain yield. Results presented by Ali et al. (2009) are also in favour to these findings, as they reported an increase in grain yield of wheat by foliar application of B and zinc. Likewise, Wroble (2009) stated that B spray at reproductive stage enhanced the grain yield in wheat. 


\section{Straw yield}

It is helpful in increasing economic return as it provides additional economic benefits to the farmer community. It is also important because it is component of benefit cost ratio of a farm. A meaningful increase in straw yield was recorded when B was sprayed at booting. Data recorded for straw yield is given in Table 2 which showed that significantly the higher straw yield $\left(5.136 \mathrm{t} \mathrm{ha}^{-1}\right)$ was recorded with $1.5 \% \mathrm{~B}$ spray at booting stage, while, the minimum straw yield $\left(4.99 \mathrm{t} \mathrm{ha}^{-1}\right)$ recorded was from control. An increase of $2.92 \%$ was observed with B spray in comparison to control. Nazim et al. (2005) also reported an upsurge in the straw yield with B spray. These findings are also in line with Muhmood et al. (2014) who observed increased straw yield with application of B.

\section{Harvest index (H.I)}

It is the measurement of efficiency of crop to translate assimilates into grain yield. Boron spray at booting stage functioned significantly in improving H.I of the wheat crop. Foliar application of $\mathrm{B}$ showed significant results as compared with control and water spray. Data (Table 2) revealed that significantly higher H.I (47.88 \%) was calculated in treatment with $1.5 \% \mathrm{~B}$ spray at booting stage. Increase in H.I was $9.1 \%$ with B spray in comparison to control. Increase in harvest index with B application has also been suggested by Khan et al. (2010). In addition, Tahir et al. (2009) have also indicated an up rise in harvest index by B spray on wheat.

\section{Biochemical parameters}

Proteins are important in any crop to determine the quality of that crop. Foliar application of B significantly enhanced protein contents of wheat grains. Data recorded is given in Table 3. Statistically, highest protein contents $(11.90 \% \%)$ were observed in treatment with $1.5 \%$ B spray at booting stage. Proteins were increased up to $6.6 \%$ with B spray. This increase in proteins may be owing to the role of $\mathrm{B}$ in enzyme activity, protein synthesis and improving uptake of nitrogen. Increase in protein content was observed by Bameri et al. (2012) because they also recorded increased proteins in wheat grains with micronutrients application. Carbohydrate contents are also an important constituent in any crop to determine quality of that crop. Data analyzed for carbohydrate contents is presented in Table 3. Boron spray significantly enhanced carbohydrate contents of wheat grains. Significantly, the highest carbohydrate contents $(66.96 \%)$ were recorded with $1.5 \%$ B spray at booting stage. Escalation in carbohydrate contents with B spray was up to $4.4 \%$. This increase in carbohydrate contents is supported by Seadh et al. (2015) as they concluded from the results that carbohydrate contents were increased with foliar spray of B on wheat when compared to control treatment.

\begin{tabular}{lll}
$\begin{array}{c}\text { Table 3: Biochemical responses of wheat (Triticum } \\
\text { aestivum } \mathbf{L} \text {.) } \\
\text { applied B different levels of foliar }\end{array}$ \\
\hline Treatment & $\begin{array}{l}\text { Protein } \\
\text { contents (\%) }\end{array}$ & $\begin{array}{l}\text { Carbohydrate } \\
\text { contents (\%) }\end{array}$ \\
\hline Control & $11.16 \mathrm{e}$ & $64.13 \mathrm{f}$ \\
Water spray & $11.20 \mathrm{de}$ & $64.46 \mathrm{ef}$ \\
0.5\% B foliar spray & $11.46 \mathrm{bcd}$ & $65.66 \mathrm{c}$ \\
1\% B foliar spray & $11.56 \mathrm{bc}$ & $66.56 \mathrm{ab}$ \\
1.5\% B foliar spray & $11.90 \mathrm{a}$ & $66.96 \mathrm{a}$ \\
2\% B foliar spray & $11.66 \mathrm{ab}$ & $66.53 \mathrm{ab}$ \\
2.5\% B foliar spray & $11.40 \mathrm{bcde}$ & $66.26 \mathrm{~b}$ \\
3\% B foliar spray & $11.36 \mathrm{cde}$ & $65.43 \mathrm{~cd}$ \\
3.5\% B foliar spray & $11.33 \mathrm{cde}$ & $65.16 \mathrm{~cd}$ \\
4\% B foliar spray & $11.30 \mathrm{cde}$ & $64.13 \mathrm{de}$ \\
LSD value & 0.26 & 0.49 \\
\hline $\begin{array}{l}\text { Values with different } \\
\text { probability of LSD test }\end{array}$ & \multicolumn{2}{l}{ sters are statistically significant at $5 \%$} \\
\hline
\end{tabular}

\section{Benefit cost ratio (BCR)}

Ratio between benefits and cost of each treatment (variables) was also calculated. Results depicted in the Table 2 exposed that the highest BCR (1.34) was calculated with $1.5 \%$ B spray at booting stage. It was $6.5 \%$ higher than control.

All the parameters showed an elevating trend up to a certain concentration of $\mathrm{B}$ sprayed, but with increasing concentration of B above pertinent level, these started to decline. Similarly, reduction in components has also been suggested by Muntean (2009) who documented that B toxicity negatively affected plant growth and thereby reduced number, size and weight of the fruit. Reid (2007) also reported negative effects of $\mathrm{B}$ toxicity on plants. Moreover, there also implies the law of diminishing returns which states that any application of fertilizer will increase yield initially but up to a certain limit. Fertilizer application above optimum level may affect negatively.

\section{Conclusion}

Data recorded for the current experiment revealed that all the levels of B sprayed at booting stage showed significantly better results over control. However, it can be concluded from the results that $1.5 \%$ B spray at booting stage produced supreme results. All the parameters were positively influenced with B spray and there was an indication of $6.7 \%$ increase in yield with $1.5 \%$ B spray at booting stage. 


\section{References}

Ahmad, R. and M. Irshad. 2011. Effect of boron application time on yield of wheat, rice and cotton crop in Pakistan. Soil and Environment 30(1): 50-57.

Ahmed, N., M. Abid, F. Ahmad, M.A. Ullah, Q. Javaid and M.A. Ali. 2011. Impact of boron fertilization on dry matter production and mineral constitution of irrigated cotton. Pakistan Journal of Botany 43: 2903-2910.

Ali, S., A. Shah, M. Arif, G. Miraj, I. Ali, M. Sajjad, Farhatullah, M.Y. Khan and N.M. Khan. 2009. Enhancement of wheat grain yield and yield components through foliar application of Zinc and Boron. Sarhad Journal of Agriculture 25: 15-19.

Arif, M., M.A. Chohan, S. Ali, R. Gul and S. Khan. 2006. Response of wheat to foliar application of nutrients. Journal of Agricultural and Biological Sciences 1: 3034.

Asad, A. and R. Rafique. 2000. Effect of zinc, copper, manganese and boron on the yield and yield components of wheat crop in Tehsil Peshawar. Pakistan Journal of Biological Sciences 3: 1615-1620.

Bameri, M., R. Abdolshahi, G. Mohammadi-Nejad, K. Yousefi and S.M. Tabatabaie. 2012. Effect of different microelement treatment on wheat (Triticum aestivum) growth and yield. International Research Journal of Applied and Basic Sciences 3: 219-223.

Brown, P.H., N. Bellaloui, M.A. Wimmer, E.S. Bassil, J. Ruiz, H. Hu, H. Pfeffer, D. Dannel and V. Romheld. 2002. Boron in plant biology. Plant Biology 4: 205-223.

Chaudhary, E.H., V. Timmer, A.S. Javed and M.T. Siddique. 2007. Short communication: Wheat response to micronutrients in rainfed areas of Punjab. Soil and Environment 26: 97-101.

Cohen, M.S. and Lepper, R. 1977. Effect of boron on cell elongation and division in squash roots. Plant Physiology 59: 884-887.

Fakir, O.A., M.A. Rahman and M. Jahiruddin. 2016. Effects of foliar application of boron (B) on the grain set and yield of wheat (Triticum aestivum L.). American Journal of Experimental Agriculture 2: 1-8.

Furlani, A.M.C., C.P. Carvalho, J.G. de Freitas and M.F. Verdial. 2003. Wheat cultivar tolerance to boron deficiency and toxicity in nutrient solution. Scientia Agricola 60: 359-370.

Imtiaz, M., A. Rashid, P. Khan, M.Y. Memon and M. Aslam. 2010. The role of micronutrients in crop production and human health. Pakistan Journal of Botany 42: 2565-2578.
Khan, M.B., M. Farooq, M.H. Shahnawaz and G. Shabir. 2010. Foliar application of micronutrients improves the wheat yield and net economic return. International Journal of Agriculture and Biology 12: 953-956.

Leghari, A.H., G.M. Laghari, M.A. Ansari, M.A. Mirjat, U.A. Laghari, S.J. Leghari, Ab.H. Laghari and Z.A. Abbasi. 2016. Effect of NPK and Boron on growth and yield of wheat variety TJ-83 at Tandojam soil. Advances in Environmental Biology 10: 209-216.

Manal, F.M., A.T. Thalooth and R.K.M. Khalifa. 2010. Effect of foliar spraying with uniconazole and micronutrients on yield and nutrients uptake of wheat plants grown under saline condition. Journal of American Science 6: 398-404.

Muhmood, A., S. Javid, A. Niaz, A. Majeed, T. Majeed and M. Anwar. 2014. Effect of boron on seed germination, seedling vigor and wheat yield. Soil and Environment 33: 17-22.

Muntean, D.W. 2009. Boron, the overlooked essential element. Soil and Plant Laboratory Inc. P.O Box 1648 Bellevue, WA 98009.

Nadim, M.A., I.U. Awan, M.S. Baloch, E.A. Khan, K. Naveed and M.A. Khan. 2012. Response of wheat (Triticum aestivum L.) to different micronutrients and their application methods. Journal of Animal and Plant Sciences 22: 113-119.

Nadim, M.A., I.U. Awan, M.S. Baloch, E.A. Khan, K. Naveed, M.A. Khan, M. Zubair and N. Hussain. 2011. Effect of micronutrients on growth and yield of wheat. Pakistan Journal of Agricultural Sciences 48: 191-196.

Nadim, M.A., I.U. Awan, M.S. Baloch, N. Khan and K. Naveed. 2013. Micronutrient use efficiency in wheat as affected by different application methods. Pakistan Journal of Botany 45: 887-892.

Narimani, H., M.M. Rahimi, A. Ahmadikhah and B. Vaezi. 2010. Study on the effects of foliar spray of micronutrient on yield and yield components of durum wheat. Archives of Applied Science Research 6: 168176.

Nazim, H., M.A. Khan and M.A. Javed. 2005. Effect of foliar application of plant micronutrient mixture on growth and yield of wheat. Pakistan Journal of Biological Sciences 8: 1096-1099.

Raza, S.A., S. Ali, Z.S. Chahill and R.M. Iqbal. 2014. Response of foliar application of boron on wheat (Triticum aestivum L.) crop in calcareous soils of Pakistan. Academia Journal of Agriculture Research 3: 106-109.

Reddy, S.R. 2004. Principles of Crop Production, Growth Regulators and Growth Analysis (2 $2^{\text {nd }}$ ed.). Kalyani Publishers, Ludhiana, India. 47-54 p. 
Rehman, A. and M. Farooq. 2013. Boron application through seed coating improves the water relations, panicle fertility, kernel yield and biofortification of fine grain aromatic rice. Acta Physiologiae Plantarum 35: 411-418.

Rehman, S.U., N. Hussain, M. Tariq, M. Hussain, M. Nasir and M. Ayaz. 2012. Response of wheat to exogenous boron supply at various growth stages. Sarhad Journal of Agriculture 28: 411-414.

Reid, R. Physiology and metabolism of boron in plants. 2007. p. 83-90. In: Advances in Plant and Animal Boron Nutrition. F. Xu, H.E. Goldbach, P.H. Brown, R.W. Bell, T. Fujiwara, C.D. Hunt, S. Goldberg and L. Shi (eds). Springer, Dordrecht. Netherlands.

Seadh, S.E., W.A.W. Abido and M.H.A. Hamada. 2015. Growth, yield and grain quality as influenced by potassium, silicon and boron foliar application under newly reclaimed sandy saline in North Nile Delta. World Research Journal of Agronomy 4: 125-133.

Shireen, F., M.A. Nawaz, C. Chen, Q. Zhang, Z. Zheng, H. Sohail, J. Sun, H. Cao, Y. Huang and Z. Bie. 2018. Boron: Functions and approaches to enhance its availability in plants for sustainable agriculture. International Journal of Molecular Sciences 19: 1-20.

Steel, R.G.D., J. H. Torrie and D.A. Dickey. 1997. Principles and Procedures of Statistics: A Biometrical Approach. McGraw Hill College Publishers. New York. 666 p.
Tahir, M., A. Tanveer, T.H. Shah, N. Fiaz and A. Wasaya. 2009. Yield response of wheat (Triticum aestivum L.) to boron application at different growth stages. Pakistan Journal of Life and Social Sciences 7: 39-42.

Torun, A., I.G.A. Itekin, M. Kalayci, A. Yilmaz, S. Eker and I. Cakmak. 2001. Effects of zinc fertilization on grain yield and shoot concentrations of zinc, boron and phosphorus of 25 wheat cultivars grown on a zinc deficient and boron toxic soil. Journal of Plant Nutrition 24:1817-1829.

Wang, Q., L. Lu, X. Wu, Y. Li and J. Lin. 2003. Boron influences pollen germination and pollen tube growth in Picea meyeri. Tree Physiology 23: 345-351.

Watson, D.J. and K.I. Hayashi. 1965. Photosynthetic and respiratory components of the net assimilation rates of sugar beet and barley. New Phytologist 64: 38-47.

Wroble, S. 2009. Response of spring wheat to foliar fertilization with boron under reduced boron availability. Journal of Elementology 14: 395-404.

Yan, X., P. Wu, H. Ling, G. Xu, F. Xu and Q. Zhang. 2006. Plant nutriomics in China: An overview. Annals of Botany 98: 473-482.

Zheng, C., Y. Zhu, H. Zhu, G. Kang, T. Guo and C. Wang. 2014. Floret development and grain setting characteristics in winter wheat in response to preanthesis applications of 6-benzylaminopurine and boron. Field Crop Research 169: 70-76. 